\title{
Estrogenic Compounds or Adiponectin Inhibit Cyclic AMP Response to Human Luteinizing Hormone in Mouse Leydig Tumor Cells
}

\author{
Thi Mong Diep Nguyen ${ }^{1,2}$, Danièle Klett ${ }^{1}$ and Yves Combarnous ${ }^{1, *(1)}$ \\ 1 Physiologie de la Reproduction et des Comportements, Institut National de la Recherche \\ Agronomique (INRA), Centre National de la Recherche Scientifique (CNRS), 37380 Nouzilly, France; \\ diepdhqn@ymail.com (T.M.D.N.); daniele.klett@inra.fr (D.K.) \\ 2 Quy Nhon University, Quy Nhơn, Vietnam \\ * Correspondence: yves.combarnous@inra.fr; Tel.: +33-247-427-650
}

Received: 23 April 2019; Accepted: 10 June 2019; Published: 11 June 2019

\begin{abstract}
Mouse Leydig Tumor cells (mLTC), transiently expressing cAMP-dependent luciferase, were used to study the influence of sexual steroids and of adiponectin (ADPN) on the cAMP response to luteinizing hormones (LH). While testosterone and progesterone had no significant effect, several molecules with estrogenic activity (17 $\beta$-estradiol, ethynylestradiol, and bisphenol A) provoked a decrease in intracellular cyclic AMP accumulation under $0.7 \mathrm{nM}$ human LH stimulation. Adiponectin exhibited a bimodal dose-effect on LH response: synergistic between $2-125 \mathrm{ng} / \mathrm{mL}$ and inhibitory between $0.5-5 \mu \mathrm{g} / \mathrm{mL}$. In brief, our data indicate that estrogens and ADPN separately exert rapid $(<1 \mathrm{~h})$ inhibitory and/or synergistic effects on cAMP response to LH in mLTC-1 cells. As the inhibitory effect of each estrogenic molecule was observed after only 1-h preincubation, it might be mediated through the G protein-coupled estrogen receptor (GPER) membrane receptor, but this remains to be demonstrated. The synergistic effect with low concentrations of ADPN with human Luteinizing Hormone (hLH) was observed with both fresh and frozen/thawed ADPN. In contrast, the inhibitory effect with high concentrations of ADPN was lost with frozen/thawed ADPN, suggesting deterioration of its polymeric structure.
\end{abstract}

Keywords: adiponectin; testosterone; progesterone; estradiol; bisphenol-A

\section{Introduction}

Leydig cells play an essential role in testicular functions and male physiology. They respond to luteinizing hormones (LH) with an increase in intracellular cyclic AMP and subsequently produce testosterone that exerts feedback control on the pituitary and stimulates male characters (behavior, muscle mass) and the development and function of accessory glands (prostate, seminal vesicle, deferens duct) [1]. Testosterone from Leydig cells also strongly influences gametogenesis through its action into Sertoli cells [2]. Mouse Leydig Tumor Cells (mLTC) are a cell line retaining many of the testicular Leydig cells' characteristics, except their steroidogenesis that almost stops at the level of progesterone production and synthesizes only small quantities of testosterone [3].

Leydig cells are targets for testosterone [4] and also for other steroid hormones [5] and, thus, we tested whether the cAMP response of mLTC cells to a submaximally stimulating concentration of human $\mathrm{LH}(0.7 \mathrm{nM})$, could be altered by testosterone or estrogens.

Adiponectin (ADPN) is a hormone involved in the control of metabolism and insulin sensitization. It is produced by mature adipocytes [6] and exhibits pleiotropic properties. It acts through two adiponectin receptors (AdipoR1 and AdipoR2), which are expressed in many cell types [7]. Besides, 
the expression of ADPN gene and protein has also been found in the reproductive system. It was noted, among others, in the hypothalamus [8] in the human endometrium, as well as the uterus, trophoblasts, and conceptuses of mice and pigs [9-11]. ADPN possesses anti-inflammatory properties for many tissues [12,13], as well as antiatherogenic and anticancerogenic properties [14-16]. It is mostly known for its role in the liver where it inhibits gluconeogenesis and stimulates glucose transport, oxidation of fatty acids, and insulin sensitivity [17], the latter also improving insulin receptor phosphorylation [18].

Gonadotropins are heterodimeric glycoprotein hormones acting through specific G Protein-Coupled Receptors (GPCR) to stimulate their target cells where $3^{\prime} 5^{\prime}$ cyclic adenosine monophosphate (cAMP) is their main intracellular second messenger. To study the intracellular signaling downstream of Luteinizing Hormone (LH) binding to LH receptor (LHR), we made use of the mLTC cell line in which we transiently expressed a cAMP-dependent luciferase. The mLTC-1 cell line has been established many years ago [3] and has been found of great interest for the study of Leydig cell sensitivity to LHs and human Chorionic Gonadotropin (hCG) in terms of binding or cAMP accumulation and steroid synthesis [19].

Steroid hormones and peptide hormones generally act via distinct mechanisms, the former most often via intracellular receptors through genomic activation [20] and the latter via membrane-localized receptors, such as the LHR, which stimulates the generation of intracellular cAMP. The cAMP-dependent kinase (PKA (protein kinase A)) and other protein kinases have also been documented to synergize with steroid hormone-occupied receptors, leading to enhanced steroid receptor-mediated transcription [21-23], possibly by a mechanism involving phosphorylation of the receptor or associated transcription factors [24-26]. In the present work, we show that estrogenic molecules, as well as ADPN, modulate human Luteinizing Hormone (hLH)-stimulated cyclic AMP accumulation in mLTC-1 cells.

\section{Materials and Methods}

\subsection{Hormones}

Recombinant human LH (hLH-C35) was from Serono (Geneva, Switzerland). Recombinant bovine adiponectin was purchased from Cusabio (Interchim, Montluçon, France). Steroid hormones were purchased from Sigma-Aldrich (Saint Quentin Fallavier, France).

\subsection{Chemicals}

All other chemicals were purchased from Sigma-Aldrich (Saint Quentin Fallavier, France) unless otherwise noted. pGlosensor-TM-22F cyclic AMP plasmid and CellTiter-Blue Cell viability assay (G8080) were from Promega (Charbonnières-les-Bains, France). XtremeGENE HP DNA transfection reagent was from Roche (Boulogne-Billancourt, France).

\subsection{Cell Culture}

The mLTC-1 cells [3] were obtained from the American Tissue and Cell Collection (ATCC) (LGC Standards, Molsheim, France). Cells were expanded in supplemented RPMI-1640 medium (Gibco, Invitrogen, $10 \%$ fetal bovine serum, $50 \mu \mathrm{g} / \mathrm{mL}$ gentamicin, 10 units of penicillin $/ \mathrm{mL}$, and $10 \mu \mathrm{g} / \mathrm{mL}$ streptomycin). All cells were grown at $37^{\circ} \mathrm{C}$ and $5 \% \mathrm{CO}_{2}$. They were used between their 5 th and 30th passage, a range in which they exhibited no decrease in their responses to LH.

\subsection{Plasmids, Transfections}

Cells (about 100,000 cells per well) on a 96-well Greiner white/clear bottom plate (Dutscher, Brumath, France) were transfected with pGlosensor-TM-22F cyclic AMP plasmid using XtremeGENE HP DNA transfection reagent. Thirty minutes before transfection, DNA (100 ng plasmid per well) and XtremeGENE HP DNA transfection reagent $(0.3 \mu \mathrm{L}$ per well) were mixed together with serum-free RPMI medium. This plasmid consists of firefly luciferase sequence fused to that of the PKA cAMP-binding domain in a way that allows control of its enzymatic activity by cyclic AMP. The plates were then incubated overnight at $37^{\circ} \mathrm{C}$ under $5 \% \mathrm{CO}_{2}$ before use in the assays. 


\section{5. cAMP Quantitation}

Transfection supernatants were removed and replaced with a medium deprived of fetal-calf serum $(100 \mu \mathrm{L})$ and containing the luciferase substrate luciferin and also $1 \mathrm{mM}$ isobutyl-methyl-xanthine (IBMX) in order to inhibit endogenous nucleotide phosphodiesterase (PDE) activity. The plates were incubated for $1 \mathrm{~h}$, before the addition of ADPN, testosterone, progesterone, $17 \beta$-estradiol (E2 $\beta$ ), ethynylestradiol (EE2), or bisphenol A (BPA) at various concentrations in a $10 \mu \mathrm{L}$-volume. The cells were then incubated for another hour and, finally, human $\mathrm{LH}$ was added in a $10 \mu \mathrm{L}$ volume in triplicate or sextuplicate wells to reach $0.7 \mathrm{nM}$ concentration. Kinetics of intracellular oxyluciferin luminescence was then recorded using a Polarstar Optima (BMG Labtech Sarl, Champigny-sur-Marne, France) luminometer.

\subsection{Area Under Curve (AUC) Calculations and Statistical Analyses}

Slope calculations by linear fitting of initial accumulation rate and statistical analyses were carried out with GraphPad Prism 5 software (GraphPad Software, San Diego, CA, USA). The slope values are expressed as means $\pm \mathrm{SD}$ of three independent experiments. For all single comparisons between each dose of sample and control, one-tailed paired Student's t-test was performed after checking for distribution normality. For all statistical analyses, $p<0.05$ was considered significant.

\section{Results}

\subsection{Effects of Steroid Hormones on LH-Stimulated cAMP Response}

Preincubation of mLTC-1 cells for 60 min with various concentrations of testosterone (Figure 1) or progesterone (not shown) had a small, but not significant, inhibitory effect on the subsequent stimulation of cAMP synthesis by $0.7 \mathrm{nM} \mathrm{hLH}$.

(A)

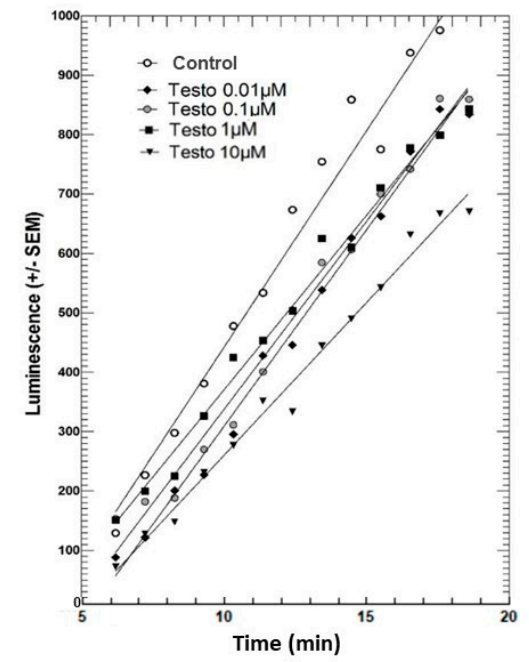

(B)

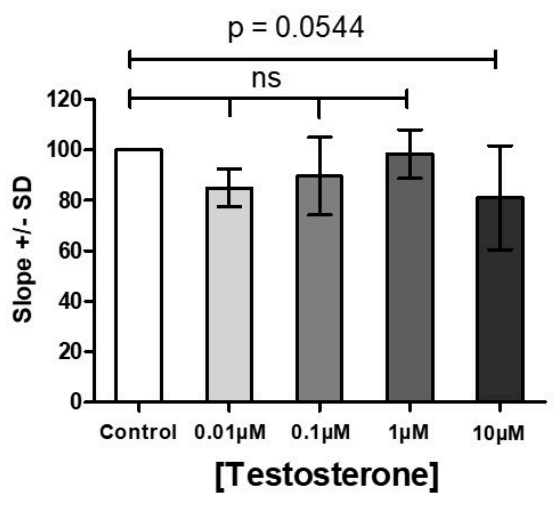

Figure 1. Effect of $1 \mathrm{~h}$-preincubation with testosterone (Testo) alone on the cAMP accumulation in Mouse Leydig Tumor cells (mLTC)- 1 cells under stimulation by $0.7 \mathrm{nM} \mathrm{hLH}$. Left (A): Kinetics of oxyluciferin luminescence produced by cAMP-dependent luciferase in mLTC-1 cells stimulated by $0.7 \mathrm{nM} \mathrm{rec} \mathrm{hLH}$ after 1h-preincubation with various concentrations of testosterone. Right (B): Dose-response effects from kinetics in panel (A). Each point represents the mean of luminescence in three wells in each condition. The figure presents one representative experiment out of three independent experiments. After checking for normal distribution, statistical analyses were performed by a paired Student's $t$-test. ns $=$ not statistically significant between each testosterone concentration and control. 
In contrast to testosterone and progesterone, estrogenic molecules (E2 $\beta, E E 2$, and BPA) exerted a marked inhibitory effect on the subsequent stimulation by hLH (Figure 2). 17 $\beta$-estradiol and EE2 at $10 \mu \mathrm{M}$ significantly lowered the cAMP response to hLH, and BPA exerted the same effect but only at a higher concentration $(100 \mu \mathrm{M})$.

(A)
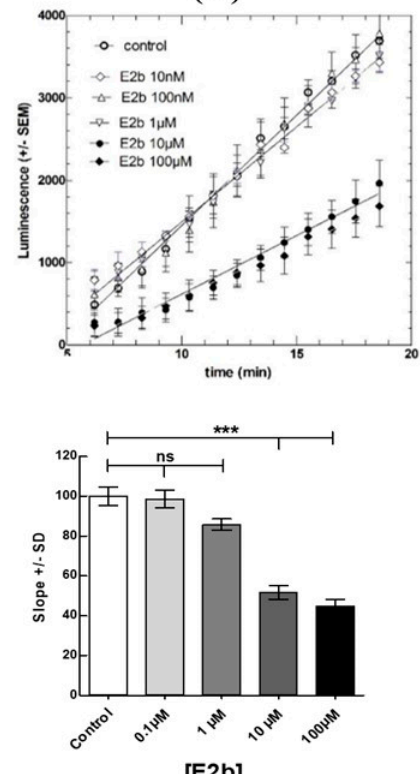

(B)
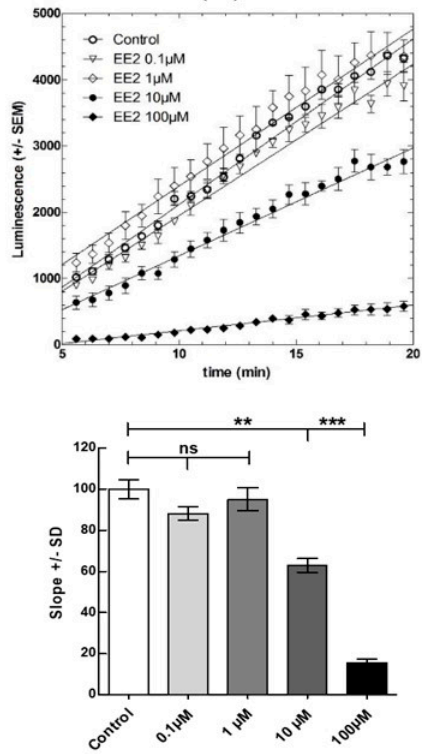

[EE2]
(C)
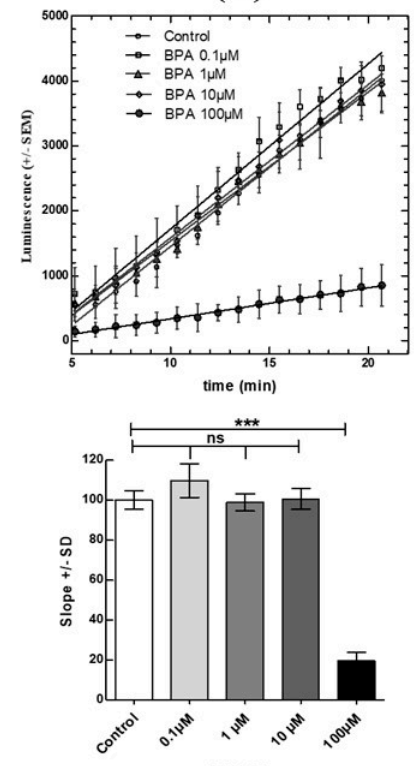

[BPA]

Figure 2. Effect of individual estrogenic molecules on the cAMP accumulation in mLTC-1 cells under stimulation by $0.7 \mathrm{nM} \mathrm{hLH}$. Kinetics of oxyluciferin luminescence after 1h-preincubation with various concentrations of (A) 17 $\beta$-estradiol (E2 $\beta$ ), (B) ethynylestradiol (EE2), and (C) bisphenol-A (BPA) are shown in the upper part. The corresponding dose-related effects are shown in the lower part. Each point represents the mean of luminescence in three wells in each condition. The figure presents one representative experiment out of three independent experiments. After checking for normal distribution, the data were analyzed by a paired Student's t-test. * indicates a significant difference (** $\left.p<0.01,{ }^{* * *} p<0.001\right)$ compared between control with each concentration of E2b or EE2 or BPA, ns $=$ not statistically significant.

In order to test whether the effects of estrogenic molecules could be exerted through the membrane-spanning $G$ protein-coupled estrogen receptor (GPER) estrogen receptor, we challenged the cells with the GPER G1 agonist but found no effect on the subsequent response of the cells to hLH (data not shown). Nevertheless, we do not consider this experiment as conclusive as we have not previously tested our G1 agonist in a cell model where GPER is known to be present and active.

\subsection{Effects of ADPN on LH-Stimulated cAMP Response}

Preincubation of mLTC- 1 cells for 60 min with various doses of recombinant bovine ADPN had a bimodal effect on the subsequent response to $0.7 \mathrm{nM} \mathrm{hLH}$ (Figure 3B,C). At low ADPN concentration (5-125 ng/mL), an increase of up to $25 \%$ in the LH-stimulated cAMP synthesis rate was observed. At higher ADPN concentrations $(0.5-5 \mu \mathrm{g} / \mathrm{mL}$ ), a decrease of about $40 \%$ was found (Figure $3 \mathrm{~B}$ ). Interestingly, when frozen and thawed ADPN was used, the potentializing effect was observed at both low and high ADPN concentrations (Figure 3C) and was only slightly less marked at the highest concentration. 
(A)

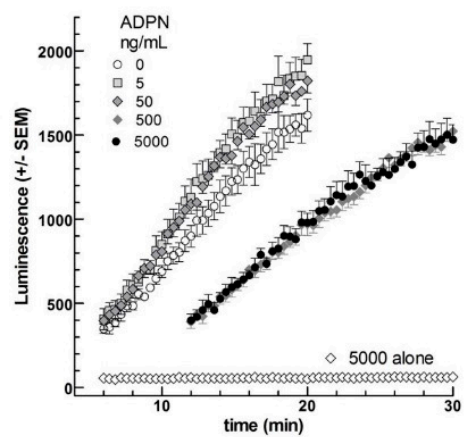

(B)

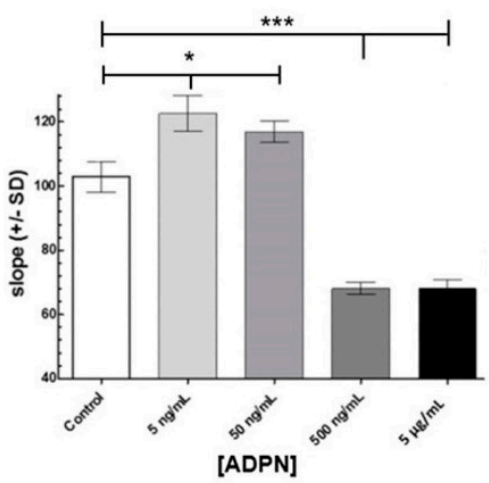

(C)

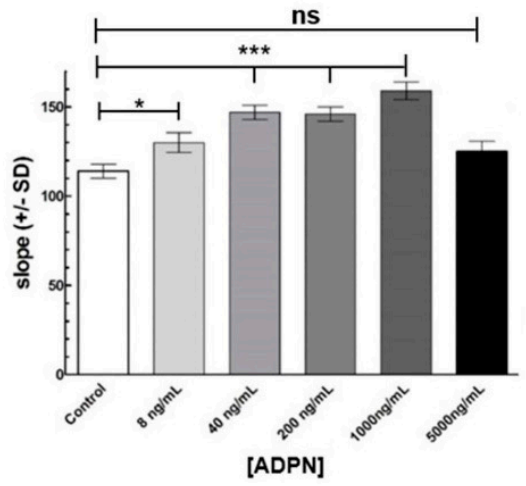

Figure 3. Effect of adiponectin (ADPN) on the cAMP response to $0.7 \mathrm{nM} \mathrm{hLH}$ in Mouse Leydig Tumor cells (mLTC)-1 cells. (A): Kinetics of oxyluciferin luminescence produced by cyclic AMP-dependent luciferase in mLTC-1 cells stimulated by $0.7 \mathrm{nM}$ rec $\mathrm{hLH}$ after 1 h-preincubation with the shown concentrations of ADPN. (B): Dose-response effects from kinetics in panel (A). (C) Dose-response effect of 1h-preincubation with frozen and thawed ADPN on the cAMP response to $0.7 \mathrm{nM} \mathrm{hLH}$. Each point represents the mean of luminescence in six wells in each condition. The figure presents one representative experiment out of three independent experiments. After checking of normality of distribution, the data were analyzed by a paired Student's t-test. * indicates a significant difference $\left({ }^{*} p<0.05,{ }^{* * *} p<0.001\right)$ compared between each ADPN concentration and control (hLH alone), ns $=$ not statistically significant.

\section{Discussion}

In the present work, we have used mLTC cells, which naturally express LH receptors $[27,28]$ and exhibit a dose-dependent cAMP response to LHs and Chorionic Gonadotropins (CGs). In previous work, we have compared the stimulation kinetics of LHs and CGs from various species in mLTC cells [29] and observed that human LH and CG exerted a strong and sustained cAMP stimulation. Recombinant hLH was thus chosen to search for possible effects of steroids and ADPN on LH-stimulated cAMP pathway in these cells. Human LH was used at $0.7 \mathrm{nM}$ concentration because it is a submaximal stimulating concentration that, thus, promotes a solid cAMP response in mLTC cells but not a saturating one.

The present results clearly demonstrate that the estrogenic compounds, but not testosterone and progesterone, rapidly inhibit intracellular cAMP accumulation under hLH stimulation in mLTC-1 cells. The observation that estrogenic compounds exert their inhibitory effect in 1-h time suggests the involvement of an estrogen membrane receptor $[30,31]$ rather than canonical nuclear receptors requiring transcriptional activity [32]. Indeed the G protein-coupled estrogen receptor (GPER) (also known as GPR30), which belongs to the GPCR family of receptors, quickly mediates the non-genomic signaling of estrogens [33]. The inhibitory mechanism of LH-stimulated cAMP accumulation by estrogens through the membrane GPER could arise through direct interaction between the two GPCRs, LHR and GPER, or at a downstream step between LHR activation and adenylate cyclase stimulation. Since LHR dimerizes upon activation by LH [34], a possible mechanism is that estrogen-occupied GPER could interfere with LHR homo-dimerization, in a way similar to the Follicle-Stimulating Hormone FSH receptor (FSHR) [35]. E2 activation of GPER leads to transactivation of the Epidermal Growth Factor Receptor (EGFR) and downstream activation of Mitogen-activated protein kinase (MAPK) and Phosphoinositide 3-kinase (PI3K) signaling cascades in breast cancer cells [36]. It is possible that in mLTC cells, one of these kinases could inhibit, by phosphorylation, the activity of the adenylate cyclase type activated downstream of LHR occupation by hLH.

It is also interesting to point out that BPA is only about 10 -fold less potent than E2 $\beta$ and EE2 in this effect, whereas it has been previously found to be approximately 10,000 -fold less efficient than these 
steroids in various long-term effects involving nuclear estrogen receptors [32]. This point deserves further investigation since BPA has been shown to exert some of its effects through GPER $[37,38]$. Nevertheless, in a preliminary experiment, we found no effect of the GPER agonist G1 on the subsequent cAMP response to LH in mLTC-1 cells. Since we did not check the activity of the G1 molecule before use in mLTC cells, we cannot conclude that this hypothesis is false and will have to study it further.

The BPA concentration, showing an effect in mLTC cells $(100 \mu \mathrm{M})$, is considerably higher than the concentration in blood circulation $(\sim 10 \mathrm{nM})$ of old people living near electronic waste dismantling facilities [39]. Then, if BPA exerts an endocrine disruptor effect through Leydig cells steroidogenesis inhibition, it must only be after long-term exposure.

Leydig cells are targets for ADPN [40,41], and they express both the high-affinity AdipoR1 and low-affinity AdipoR2 receptors [40,42,43]. In the present work, ADPN at very low concentration was found to exert a potentializing effect on the cyclic AMP response to LH. This potentiation was observed after a 1-h preincubation of mLTC-1 cells with an ADPN concentration as low as $2 \mathrm{ng} / \mathrm{mL}$. This concentration is more than 2000-fold lower than circulating ADPN concentrations $(\sim 4-15 \mu \mathrm{g} / \mathrm{mL})$ in mammals blood [44,45]. Since ADPN has been shown to be expressed in rat Leydig cells [40], a possible autocrine role can be suggested in spite of the high circulating concentration in blood.

ADPN forms oligomers from trimer to 18-mer [46], but it is not well known which of them are the most active biologically. The commercial recombinant ADPN that we used in the present work was not characterized by this point of view. Using extemporaneously dissolved ADPN, we observed first an enhancement of cAMP accumulation at the lowest ADPN concentration and then an inhibition at higher concentrations (Figure 3B). In contrast, with frozen and thawed ADPN, we only observed the enhancement phase at low concentration but not the inhibitory one at higher concentrations (Figure $3 \mathrm{C}$ ). It can be hypothesized that the forms of ADPN responsible for the inhibition of LH-stimulated cAMP accumulation were denatured during the freezing-thawing process as it is in redox changes [47]. The forms of ADPN responsible for these two effects might differ in their monomer numbers [48].

ADPN has been shown to act intracellularly through several pathways, and AMPK has been shown to be involved in many of its actions [49-53]. A previous paper reported a role for AMPK activity in mLTC-1 response to hCG [54], but it was essentially involved beyond cAMP accumulation, i.e., on steroidogenic acute regulatory protein (StAR)-promoted cholesterol entry into mitochondria and on progesterone synthesis. AMPK has been shown to be involved in another Leydig cell line (TM3) as an intermediate in NFkB suppression by ADPN [41]. This indicates that ADPN receptors are present in Leydig cells, and it will be interesting to test whether this hormone also modulates the steroidogenic responses to LH in testicular Leydig cells through AMPK control.

\section{Conclusions}

We report in the present paper, fast effects of both, estrogenic compounds and adiponectin, on LH-stimulated cyclic AMP accumulation in mLTC-1 cells. For the time being, the pathways are not known with sufficient precision to tackle the issue of possible cross inhibitions or synergies between them. Future studies in this direction would nevertheless be interesting to perform, considering in particular, the central role played by Peroxisome Proliferator-Activated Recptor $\gamma$ PPAR $\gamma$ in both pathways $[32,55,56]$.

Author Contributions: Conceptualization, T.M.D.N. and Y.C.; methodology, T.M.D.N. and D.K.; formal analysis, T.M.D.N., D.K. and Y.C.; investigation, T.M.D.N. and Y.C.; resources, Y.C.; data curation, T.M.D.N. and D.K.; writing-original draft preparation, T.M.D.N. and Y.C.; writing-review and editing, T.M.D.N. and Y.C.; supervision, Y.C.

Funding: This research received no external funding.

Acknowledgments: We are indebted to Sébastien Elis \& Alice Desmarchais (INRA, PRC, Nouzilly) for their kind gift of purified adiponectin. We also thank Laura Filliatreau (INRA, PRC, Nouzilly) for her technical help in some of the experiments.

Conflicts of Interest: The authors declare no conflict of interest. 


\section{References}

1. Zirkin, B.R.; Papadopoulos, V. Leydig cells: Formation, function, and regulation. Biol. Reprod. 2018, 99, 101-111. [CrossRef]

2. Dimitriadis, F.; Tsiampali, C.; Chaliasos, N.; Tsounapi, P.; Takenaka, A.; Sofikitis, N. The Sertoli cell as the orchestra conductor of spermatogenesis: Spermatogenic cells dance to the tune of testosterone. Hormones 2015, 14, 479-503. [CrossRef]

3. Rebois, R.V. Establishment of gonadotropin-responsive murine leydig tumor cell line. J. Cell Biol. 1982, 94, 70-76. [CrossRef]

4. O’Hara, L.; McInnes, K.; Simitsidellis, I.; Morgan, S.; Atanassova, N.; Slowikowska-Hilczer, J.; Kula, K.; Szarras-Czapnik, M.; Milne, L.; Mitchell, R.T.; et al. Autocrine androgen action is essential for Leydig cell maturation and function, and protects against late-onset Leydig cell apoptosis in both mice and men. FASEB J. 2015, 29, 894-910. [CrossRef]

5. Akingbemi, B.T.; Ge, R.; Rosenfeld, C.S.; Newton, L.G.; Hardy, D.O.; Catterall, J.F.; Lubahn, D.B.; Korach, K.S.; Hardy, M.P. Estrogen receptor-alpha gene deficiency enhances androgen biosynthesis in the mouse Leydig cell. Endocrinology 2003, 144, 84-93. [CrossRef]

6. Ahima, R.S. Metabolic actions of adipocyte hormones: Focus on adiponectin. Obesity 2006, 14 (Suppl. 1), 9S-15S. [CrossRef]

7. Yamauchi, T.; Iwabu, M.; Okada-Iwabu, M.; Kadowaki, T. Adiponectin receptors: A review of their structure, function and how they work. Best Pract. Res. Clin. Endocrinol. Metab. 2014, 28, 15-23. [CrossRef]

8. Kos, K.; Harte, A.L.; da Silva, N.F.; Tonchev, A.; Chaldakov, G.; James, S.; Snead, D.R.; Hoggart, B.; O’Hare, J.P.; McTernan, P.G.; et al. Adiponectin and resistin in human cerebrospinal fluid and expression of adiponectin receptors in the human hypothalamus. J. Clin. Endocrinol. Metab. 2007, 92, 1129-1136. [CrossRef]

9. Takemura, Y.; Osuga, Y.; Yamauchi, T.; Kobayashi, M.; Harada, M.; Hirata, T.; Morimoto, C.; Hirota, Y.; Yoshino, O.; Koga, K.; et al. Expression of adiponectin receptors and its possible implication in the human endometrium. Endocrinology 2006, 147, 3203-3210. [CrossRef]

10. Kim, S.T.; Marquard, K.; Stephens, S.; Louden, E.; Allsworth, J.; Moley, K.H. Adiponectin and adiponectin receptors in the mouse preimplantation embryo and uterus. Hum. Reprod. 2011, 26, 82-95. [CrossRef]

11. Smolinska, N.; Maleszka, A.; Dobrzyn, K.; Kiezun, M.; Szeszko, K.; Kaminski, T. Expression of adiponectin and adiponectin receptors 1 and 2 in the porcine uterus, conceptus, and trophoblast during early pregnancy. Theriogenology 2014, 82, 951-965. [CrossRef] [PubMed]

12. Yamauchi, T.; Kamon, J.; Waki, H.; Terauchi, Y.; Kubota, N.; Hara, K.; Mori, Y.; Ide, T.; Murakami, K.; Tsuboyama-Kasaoka, N.; et al. The fat-derived hormone adiponectin reverses insulin resistance associated with both lipoatrophy and obesity. Nat. Med. 2001, 7, 941-946. [CrossRef] [PubMed]

13. Nigro, E.; Scudiero, O.; Sarnataro, D.; Mazzarella, G.; Sofia, M.; Bianco, A.; Daniele, A. Adiponectin affects lung epithelial A549 cell viability counteracting TNFalpha and IL-1ss toxicity through AdipoR1. Int. J. Biochem. Cell Biol. 2013, 45, 1145-1153. [CrossRef] [PubMed]

14. Kelesidis, I.; Kelesidis, T.; Mantzoros, C.S. Adiponectin and cancer: A systematic review. Br. J. Cancer 2006, 94, 1221-1225. [CrossRef] [PubMed]

15. Goldstein, B.J.; Scalia, R. Adiponectin: A novel adipokine linking adipocytes and vascular function. J. Clin. Endocrinol. Metab. 2004, 89, 2563-2568. [CrossRef]

16. Yamauchi, T.; Kamon, J.; Minokoshi, Y.; Ito, Y.; Waki, H.; Uchida, S.; Yamashita, S.; Noda, M.; Kita, S.; Ueki, K.; et al. Adiponectin stimulates glucose utilization and fatty-acid oxidation by activating AMP-activated protein kinase. Nat. Med. 2002, 8, 1288-1295. [CrossRef] [PubMed]

17. Wu, X.; Motoshima, H.; Mahadev, K.; Stalker, T.J.; Scalia, R.; Goldstein, B.J. Involvement of AMP-activated protein kinase in glucose uptake stimulated by the globular domain of adiponectin in primary rat adipocytes. Diabetes 2003, 52, 1355-1363. [CrossRef]

18. Ye, R.; Scherer, P.E. Adiponectin, driver or passenger on the road to insulin sensitivity? Mol. Metab. 2013, 2, 133-141. [CrossRef]

19. Combarnous, Y.; Guillou, F.; Martinat, N. Functional states of the luteinizing hormone/choriogonadotropin -receptor complex in rat Leydig cells. J. Biol. Chem. 1986, 261, 6868-6871.

20. Gronemeyer, H. Transcription activation by estrogen and progesterone receptors. Annu. Rev. Genet. 1991, 25, 89-123. [CrossRef] 
21. Fujimoto, N.; Katzenellenbogen, B.S. Alteration in the agonist/antagonist balance of antiestrogens by activation of protein kinase A signaling pathways in breast cancer cells: Antiestrogen selectivity and promoter dependence. Mol. Endocrinol. 1994, 8, 296-304. [PubMed]

22. Gruol, D.J.; Altschmied, J. Synergistic induction of apoptosis with glucocorticoids and $3^{\prime}, 5^{\prime}$-cyclic adenosine monophosphate reveals agonist activity by RU 486. Mol. Endocrinol. 1993, 7, 104-113. [PubMed]

23. Beck, C.A.; Weigel, N.L.; Moyer, M.L.; Nordeen, S.K.; Edwards, D.P. The progesterone antagonist RU486 acquires agonist activity upon stimulation of cAMP signaling pathways. Proc. Natl. Acad. Sci. USA 1993, 90, 4441-4445. [CrossRef] [PubMed]

24. Somers, J.P.; DeFranco, D.B. Effects of okadaic acid, a protein phosphatase inhibitor, on glucocorticoid receptor-mediated enhancement. Mol. Endocrinol. 1992, 6, 26-34. [PubMed]

25. Ali, S.; Metzger, D.; Bornert, J.M.; Chambon, P. Modulation of transcriptional activation by ligand-dependent phosphorylation of the human oestrogen receptor A/B region. EMBO J. 1993, 12, 1153-1160. [CrossRef] [PubMed]

26. Le Goff, P.; Montano, M.M.; Schodin, D.J.; Katzenellenbogen, B.S. Phosphorylation of the human estrogen receptor. Identification of hormone-regulated sites and examination of their influence on transcriptional activity. J. Biol. Chem. 1994, 269, 4458-4466. [PubMed]

27. Catt, K.J.; Dufau, M.L.; Tsuruhara, T. Studies on a radioligand-receptor assay system for luteinizing hormone and chorionic gonadotropin. J. Clin. Endocrinol. Metab. 1971, 32, 860-863. [CrossRef]

28. Catt, K.J.; Dufau, M.L.; Tsuruhara, T. Radioligand-receptor assay of luteinizing hormone and chorionic gonadotropin. J. Clin. Endocrinol. Metab. 1972, 34, 123-132. [CrossRef]

29. Klett, D.; Meslin, P.; Relav, L.; Nguyen, T.M.; Mariot, J.; Jegot, G.; Cahoreau, C.; Combarnous, Y. Low reversibility of intracellular cAMP accumulation in mouse Leydig tumor cells (MLTC-1) stimulated by human Luteinizing Hormone (hLH) and Chorionic Gonadotropin (hCG). Mol. Cell. Endocrinol. 2016, 434, 144-153. [CrossRef]

30. Kotula-Balak, M.; Pawlicki, P.; Milon, A.; Tworzydlo, W.; Sekula, M.; Pacwa, A.; Gorowska-Wojtowicz, E.; Bilinska, B.; Pawlicka, B.; Wiater, J.; et al. The role of G-protein-coupled membrane estrogen receptor in mouse Leydig cell function-in vivo and in vitro evaluation. Cell Tissue Res. 2018, 374, 389-412. [CrossRef]

31. Milon, A.; Pawlicki, P.; Rak, A.; Mlyczynska, E.; Płachno, B.J.; Tworzydlo, W.; Gorowska-Wojtowicz, E.; Bilinska, B.; Kotula-Balak, M. Telocytes are localized to testis of the bank vole (Myodes glareolus) and are affected by lighting conditions and G-coupled membrane estrogen receptor (GPER) signaling. Gen. Comp. Endocrinol. 2019, 271, 39-48. [CrossRef] [PubMed]

32. Yasar, P.; Ayaz, G.; User, S.D.; Gupur, G.; Muyan, M. Molecular mechanism of estrogen-estrogen receptor signaling. Reprod. Med. Biol. 2017, 16, 4-20. [CrossRef] [PubMed]

33. Filardo, E.J.; Thomas, P. Minireview: G Protein-Coupled Estrogen Receptor-1, GPER-1: Its Mechanism of Action and Role in Female Reproductive Cancer, Renal and Vascular Physiology. Endocrinology 2012, 153, 2953-2962. [CrossRef] [PubMed]

34. Zhang, M.; Guan, R.; Segaloff, D.L. Revisiting and questioning functional rescue between dimerized LH receptor mutants. Mol. Endocrinol. 2012, 26, 655-668. [CrossRef] [PubMed]

35. Feng, X.; Zhang, M.; Guan, R.; Segaloff, D.L. Heterodimerization between the lutropin and follitropin receptors is associated with an attenuation of hormone-dependent signaling. Endocrinology 2013, 154, 3925-3930. [CrossRef] [PubMed]

36. Scaling, A.L.; Prossnitz, E.R.; Hathaway, H.J. GPER mediates estrogen-induced signaling and proliferation in human breast epithelial cells and normal and malignant breast. Horm. Cancer 2014, 5, 146-160. [CrossRef] [PubMed]

37. Fitzgerald, A.C.; Peyton, C.; Dong, J.; Thomas, P. Bisphenol A and Related Alkylphenols Exert Nongenomic Estrogenic Actions Through a G Protein-Coupled Estrogen Receptor 1 (Gper)/Epidermal Growth Factor Receptor (Egfr) Pathway to Inhibit Meiotic Maturation of Zebrafish Oocytes. Biol. Reprod. 2015, 93, 135. [CrossRef]

38. Acconcia, F.; Pallottini, V.; Marino, M. Molecular Mechanisms of Action of BPA. Dose Response $2015,13$. [CrossRef]

39. Song, S.; Duan, Y.; Zhang, T.; Zhang, B.; Zhao, Z.; Bai, X.; Xie, L.; He, Y.; Ouyang, J.-P.; Huang, X.; et al. Serum concentrations of bisphenol $\mathrm{A}$ and its alternatives in elderly population living around e-waste recycling facilities in China: Associations with fasting blood glucose. Ecotoxicol. Environ. Saf. 2019, 169, 822-828. [CrossRef] 
40. Caminos, J.E.; Nogueiras, R.; Gaytan, F.; Pineda, R.; Gonzalez, C.R.; Barreiro, M.L.; Castano, J.P.; Malagon, M.M.; Pinilla, L.; Toppari, J.; et al. Novel expression and direct effects of adiponectin in the rat testis. Endocrinology 2008, 149, 3390-3402. [CrossRef]

41. Wu, L.; Xu, B.; Fan, W.; Zhu, X.; Wang, G.; Zhang, A. Adiponectin protects Leydig cells against proinflammatory cytokines by suppressing the nuclear factor-kappaB signaling pathway. FEBS J. 2013, 280, 3920-3927. [CrossRef] [PubMed]

42. Landry, D.; Pare, A.; Jean, S.; Martin, L.J. Adiponectin influences progesterone production from MA-10 Leydig cells in a dose-dependent manner. Endocrine 2015, 48, 957-967. [CrossRef] [PubMed]

43. Ocon-Grove, O.M.; Krzysik-Walker, S.M.; Maddineni, S.R.; Hendricks, G.L., 3rd; Ramachandran, R. Adiponectin and its receptors are expressed in the chicken testis: Influence of sexual maturation on testicular ADIPOR1 and ADIPOR2 mRNA abundance. Reproduction 2008, 136, 627-638. [CrossRef] [PubMed]

44. Hoffstedt, J.; Arvidsson, E.; Sjolin, E.; Wahlen, K.; Arner, P. Adipose tissue adiponectin production and adiponectin serum concentration in human obesity and insulin resistance. J. Clin. Endocrinol. Metab. 2004, 89, 1391-1396. [CrossRef] [PubMed]

45. Orio, F., Jr.; Palomba, S.; Cascella, T.; Milan, G.; Mioni, R.; Pagano, C.; Zullo, F.; Colao, A.; Lombardi, G.; Vettor, R. Adiponectin levels in women with polycystic ovary syndrome. J. Clin. Endocrinol. Metab. 2003, 88, 2619-2623. [CrossRef] [PubMed]

46. Tsao, T.S. Assembly of adiponectin oligomers. Rev. Endocr. Metab. Disord. 2014, 15, 125-136. [CrossRef] [PubMed]

47. Briggs, D.B.; Giron, R.M.; Malinowski, P.R.; Nunez, M.; Tsao, T.S. Role of redox environment on the oligomerization of higher molecular weight adiponectin. BMC Biochem. 2011, 12, 24. [CrossRef]

48. Horakova, D.; Stepanek, L.; Nagelova, R.; Pastucha, D.; Azeem, K.; Kollarova, H. Total and high-molecular -weight adiponectin levels and prediction of insulin resistance. Endokrynol. Pol. 2018, 69, 375-380.

49. Hu, J.; Cui, W.; Ding, W.; Gu, Y.; Wang, Z.; Fan, W. Globular Adiponectin Attenuated H2O2-Induced Apoptosis in Rat Chondrocytes by Inducing Autophagy Through the AMPK/mTOR Pathway. Cell. Physiol. Biochem. 2017, 43, 367-382. [CrossRef]

50. Wang, S.; Miao, J.; Qu, M.; Yang, G.Y.; Shen, L. Adiponectin modulates the function of endothelial progenitor cells via AMPK/eNOS signaling pathway. Biochem. Biophys. Res. Commun. 2017, 493, 64-70. [CrossRef]

51. Chen, Y.; Zheng, Y.; Liu, L.; Lin, C.; Liao, C.; Xin, L.; Zhong, S.; Cheng, Q.; Zhang, L. Adiponectin Inhibits TNF-alpha-Activated PAI-1 Expression Via the cAMP-PKA-AMPK-NF-kappaB Axis in Human Umbilical Vein Endothelial Cells. Cell. Physiol. Biochem. 2017, 42, 2342-2352. [CrossRef] [PubMed]

52. Schindler, M.; Pendzialek, M.; Grybel, K.J.; Seeling, T.; Gurke, J.; Fischer, B.; Navarrete Santos, A. Adiponectin stimulates lipid metabolism via AMPK in rabbit blastocysts. Hum. Reprod. 2017, 32, 1382-1392. [CrossRef] [PubMed]

53. Wang, Y.; Zhang, J.; Zhang, L.; Gao, P.; Wu, X. Adiponectin attenuates high glucose-induced apoptosis through the AMPK/p38 MAPK signaling pathway in NRK-52E cells. PLoS ONE 2017, 12, e0178215.

54. Abdou, H.S.; Bergeron, F.; Tremblay, J.J. A cell-autonomous molecular cascade initiated by AMP-activated protein kinase represses steroidogenesis. Mol. Cell. Biol. 2014, 34, 4257-4271. [CrossRef] [PubMed]

55. Gorowska-Wojtowicz, E.; Dutka, P.; Kudrycka, M.; Pawlicki, P.; Milon, A.; Plachno, B.J.; Tworzydlo, W.; Pardyak, L.; Kaminska, A.; Hejmej, A.; et al. Regulation of steroidogenic function of mouse Leydig cells: G-coupled membrane estrogen receptor and peroxisome proliferator-activated receptor partnership. J. Physiol. Pharmacol. 2018, 69, 373-390.

56. Zheng, F.; Zhang, S.; Lu, W.; Wu, F.; Yin, X.; Yu, D.; Pan, Q.; Li, H. Regulation of insulin resistance and adiponectin signaling in adipose tissue by liver $X$ receptor activation highlights a cross-talk with PPARgamma. PLoS ONE 2014, 9, e101269. [CrossRef] [PubMed]

(C) 2019 by the authors. Licensee MDPI, Basel, Switzerland. This article is an open access article distributed under the terms and conditions of the Creative Commons Attribution (CC BY) license (http://creativecommons.org/licenses/by/4.0/). 